2. Мариненко Е.Е. Основы получения и использования биотоплива для решения вопросов энергосбережения и охраны окружающей среды в сельском хозяйстве. Учебное пособие / Волгоград: Изд-во ВолгГАСА, 2003. - 100 с.

3. [Электронный ресурс]. - Режим доступа: www.agrobiogaz.ru

\title{
Продуктивность смородины чёрной и устойчивость к фитопатогенам в условиях Брянской области
}

\section{Лазарев М.С., студент, ФГБОУ ВО «Брянский государственный аграрный университет», с. Кокино, Брянская обл. E-mail: aniri0509@yandex.ru}

\author{
Научный руководитель: \\ д.с.-х.н., доцент Сазонов Ф.Ф.
}

В условиях средней полосы России одним из надежных и эффективных источников увеличения потребления витаминной продукции являются ягодные культуры, возделывание которых имеет существенные преимущества по сравнению с рядом древесных плодовых пород. Малогабаритные ягодные растения отличаются быстрым вступлением в плодоношение, ранним сроком созревания плодов, высокими и регулярными урожаями, надежной адаптацией к условиям выращивания, технологичностью возделывания [1, стр. 89].

Смородина чёрная - популярная ягодная культура, широко возделываемая во многих регионах страны. Она считается одним из лучших видов ягодного сырья, особенно при производстве джема, мармелада, сока и напитков на его основе [10, стр. 29]. Установлено, что потенциальная урожайность лучших современных сортов смородины чёрной достигает 50-60 т/га, а фактическая - не превышает 10 т/га. В производственных условиях урожайность ещё ниже - не более 3-5 т/га [9, стр. 3].

Основным лимитирующим факторам, сдерживающим увеличение производственных посадок смородины чёрной, является низкая адаптация основного культивируемого сортимента к воздействию неблагоприятных факторов внешней среды, что, как следствие, снижает урожайность насаждений [3, стр. 81]. Альтернативой в реализации потенциала культуры является возделывание адаптированных к местным условиям сортов, отличающихся высокой продуктивностью и самоплодностью [2, стр. 4]. Подобные генотипы позволяют избежать воздействия экологических стрессоров, не требуют применения средств защиты растений от болезней и вредителей, что снижает себестоимость возделывания [7, стр. 11].

Существует тесная связь между потенциальной продуктивностью сорта и его способностью противостоять различным дестабилизирующим воздействиям [4, стр. 36]. Болезни и вредители - серьёзный сдерживающий фактор расширения и роста продуктивности насаждений большинства ягодных культур [6, стр. 16]. От воздействия грибковых болезней и вредителей потери в эпифитотийные сезоны достигают 50\% при резком снижении качества продукции. Причём их концентрация на товарных плантациях с возрастом только возрастает [3, стр. 83]. 
Исследования проводились в 2014-2016 гг. в коллекционном саду Кокинского опорного пункта ФГБНУ ВСТИСП и кафедры луговодства, селекции, семеноводства и плодоовощеводства Брянского ГАУ согласно общепринятой методике [5, стр. 351]. Агротехника возделывания смородины чёрной - общепринятая для средней полосы России. Земельный участок, где проводились исследования, представлен серыми лесными почвами, суглинистыми по механическому составу, с мощностью гумусового горизонта около 25 см. Содержание фосфора и калия в почве довольно высокое (38 мг $\mathrm{P}_{2} \mathrm{O}_{5}$ и 32 мг $\mathrm{K}_{2} \mathrm{O}$ на 100 г почвы). Гумуса в верхних слоях - 3,2\%, pH 6,06.

В настоящее время известно более 200 видов грибковых болезней и вредителей, наносящих вред смородине чёрной. Массовым стала восприимчивость смородины чёрной к американской мучнистой росе и листовым пятнистостям (антракноз, септориоз) [8, стр. 15]. В наших условиях мучнистой росой поражались листья, побеги и очень редко завязь и ягоды. На основании проведенных исследований сорта и формы смородины чёрной были разделены на три группы: устойчивые, среднеустойчивые и неустойчивые. В группу устойчивых к болезни (балл поражения не более 1,5) вошли сорта Багира, Бармалей, Black Reward, Bepa, Вертикаль, Гамаюн, Гамма, Грация, Гулливер, Дар Смольяниновой, Дачница, Дебрянск, Дегтярёвская, Деликатес, Загадка, Заря Галицкая, Исток, Калиновка, Кипиана, Лама, Литвиновская, Миф, Нара, Орловия, Орловская серенада, Орловский вальс, Память Вавилова, Подарок ветеранам, Рита, Санюта, Севчанка, Селеченская 2, Созвездие, Стрелец, Тамерлан, Титания, Трилена, Черешнёва, Чудное мгновение, Шаровидная.

Наиболее сильно (более 3,5 баллов) мучнистой росой были поражены сорта Аметист, Венера, Воспоминание, Галинка, Глобус, Жемчужина, Зелёная дымка, Изюмная, Краса Львова, Легенда, Памяти Равкина, Романтика, Ртищевская, Боровчанка, Любава, Дубровская, Бирюлевская, Дочка, Пигмей, Черный жемчуг, Татьянин день, Челябинская, Экзотика и Эффект. В результате поражений эти генотипы потеряли урожай в результате осыпания на 40-50\%.

Оценка существующего сортимента показала, что высокую полевую устойчивость (балл поражения не более 1,5) к листовым пятнистостям в условиях Брянской области проявляют сорта Бармалей, Black Reward, Bepa, Гамаюн, Гамма, Грация, Гулливер, Деликатес, Исток, Кипиана, Кудесник, Литвиновская, Миф, Орловия, Подарок ветеранам, Рита, Севчанка, Стрелец, Тамерлан.

Анализ коллекционного материала (2016 г.) показал, что 24\% сортов из 137 изученных были без признаков повреждения почковым клещом. В группу высокоустойчивых к этому вредителю отнесены сорта Бинар, Глариоза, Изюмная, Искушение, Грация, Шалунья, Дар Смольяниновой, Миф, Монисто, Десертная Ольхиной, Добрыня, Кипиана, Ладушка, Tiben, Литвиновская, Софиевская, Маленький принц, Вера, Ожерелье, Черешнева, Очарование, Санюта, Семирамида, Сладкоплодная, Челябинская, Чудное мгновение, Этюд. Также высокую устойчивость к почковому клещу на уровне иммунитета показали формы 9-30-1/02 (Изюмная х Орловия), 10-141-2 (Стрелец х Голубичка), 32-1-02 (Гамма х Изюмная), 4-30-2 (Изюмная х Ядрёная), 8-4-5 (Ядрёная х Экзотика), 10-29-1/02 (Монисто х Бинар), 36-17-8 (8-4-1 свободное опыление) селекции Кокинского опорного пункта ФГБНУ ВСТИСП.

Среди представленных сортов в группу крупноплодных (средняя масса ягод 1,5 г и более) выделены сорта Бармалей, Исток, Кудесник, Литвиновская, Тамерлан, Подарок ветеранам, Стрелец (табл. 1). Все они активно используются в дальнейшей 
селекционной работе как источники высокой полевой устойчивости к листовым пятнистостям, мучнистой росе и крупноплодности.

В неблагоприятный для формирования урожая период вегетации 2015 года урожайность не снижалась ниже 4,2 т/га (Деликатес). При этом максимальный уровень урожайности в сухой 2014 год у некоторых сортов превышал 10,5 т/га (Селеченская 2, Литвиновская, Исток). Это свидетельствует о возможности отбора генотипов, способных регулярно плодоносить даже в неблагоприятные для формирования урожая годы.

Таблица 1

Продуктивность и урожайность смородины чёрной в условиях Брянской области (2014-2016 гг.)

\begin{tabular}{|l|c|c|c|c|c|}
\hline \multirow{2}{*}{ Сорт } & \multirow{2}{*}{$\begin{array}{c}\text { Средняя } \\
\text { масса } \\
\text { ягод, г. }\end{array}$} & \multicolumn{2}{|c|}{ Продуктивность, кг/куст } & \multicolumn{2}{|c|}{$\begin{array}{c}\text { Урожайность в } \\
\text { среднем за 3 года }\end{array}$} \\
\cline { 3 - 6 } & 1,5 & 6,1 & 2,3 & 9,6 & 7,7 \\
\hline Бармалей & 1,0 & 2,4 & 1,7 & 7,1 & 10,2 \\
\hline Black Reward & 1,4 & 5,0 & 2,2 & 9,2 & 12,5 \\
\hline Вера & 1,4 & 4,9 & 2,7 & 11,3 & 9,2 \\
\hline Гамаюн & 1,2 & 2,3 & 1,9 & 7,9 & 11,3 \\
\hline Гамма & 1,2 & 2,6 & 2,7 & 11,3 & 12,5 \\
\hline Грация & 1,2 & 4,9 & 2,6 & 10,8 & 8,6 \\
\hline Гулливер (st) & 1,1 & 2,6 & 1,5 & 6,3 & 17,1 \\
\hline Деликатес & 2,2 & 5,5 & 2,7 & 11,3 & 5,9 \\
\hline Исток & 1,2 & 4,4 & 2,6 & 10,8 & 13,6 \\
\hline Кипиана & 2,2 & 4,3 & 2,6 & 10,8 & 5,3 \\
\hline Кудесник & 1,6 & 5,1 & 2,7 & 11,3 & 7,3 \\
\hline Литвиновская & 1,4 & 2,7 & 2,6 & 10,8 & 8,1 \\
\hline Миф & 1,2 & 2,0 & 1,5 & 6,3 & 18,1 \\
\hline Орловия & 1,7 & 4,8 & 2,7 & 11,3 & 9,5 \\
\hline Подарок ветеранам & 1,2 & 3,7 & 2,0 & 8,3 & 8,7 \\
\hline Рита & 1,1 & 3,1 & 1,8 & 7,5 & 12,5 \\
\hline Севчанка & 1,5 & 4,7 & 2,5 & 10,4 & 9,0 \\
\hline Стрелец & 1,5 & 3,3 & 2,3 & 9,6 & 10,6 \\
\hline Тамерлан & 0,19 & 0,23 & 0,18 & 2,04 & - \\
\hline НСР 0,05 & & & & & \\
\hline
\end{tabular}

По результатам исследований за 2014-2016 годы наибольшей урожайностью отличались сорта: Гамаюн, Исток, Подарок ветеранам - 11,3 т/га; Гулливер, Кипиана, Кудесник, Миф - 10,8 т/га; Стрелец - 10,4 т/га. При этом высокую гомеостатичность (коэффициент вариации $\mathrm{V}<10 \%$ ) проявили сорта Бармалей, Гамаюн, Гулливер, Исток, Кудесник, Литвиновская, Миф, Подарок ветеранам, Рита, Стрелец, что подтверждает их высокую экологическую пластичность.

Bce выделенные сорта представляют значительный интерес, как для промышленного садоводства, так и для использования в личных подсобных хозяйствах средней полосы России. Они включены в селекционный процесс, и их использование в дальнейшей работе, несомненно, качественно улучшит исходный материал и ускорит создание более совершенного сортимента смородины чёрной. 


\title{
Список литературы:
}

1. Айтжанова С.Д. Селекция земляники на улучшение качественных показателей ягод / С.Д. Айтжанова, В.И. Андронов, Ф.Ф. Сазонов // Сб. докладов и сообщений ХІХ Мичуринских чтений «Современные проблемы генетики и селекции плодовых и ягодных культур и пути их решения» (27-29 октября 1998 г). - Мичуринск: Изд-во ВНИИГиСПР им. И.В. Мичурина, 1999. - С. 89-91.

2. Астахов А.И. Самоплодность сортов чёрной смородины / А.И. Астахов, Ф.Ф. Сазонов // Садоводство и виноградарство. - М., 2007. - № 2. - С. 4-6.

3. Казаков И.В. Оценка и создание исходного материала смородины черной для приоритетных направлений селекции / И.В. Казаков, Ф.Ф. Сазонов // Современное состояние культур смородины и крыжовника: Сб. науч. тр. / ВНИИС им. И.В. Мичурина. - Мичуринск, 2007. - С. 81-90.

4. Казаков И.В. Селекционная оценка родительских форм смородины чёрной на устойчивость к антракнозу и септориозу/ И.В. Казаков, Ф.Ф. Сазонов // Плодоводство и ягодоводство России: Сб. науч. работ / ГНУ ВСТИСП Россельхозакадемии. - М., 2010. - T. XXIV, ч. 2. - C. 35-43.

5. Программа и методика сортоизучения плодовых, ягодных и орехоплодных культур. - Орёл, 1999. - С. 351-373.

6. Сазонов Ф.Ф. Современный сортимент смородины чёрной и исходный материал в селекции / Ф.Ф. Сазонов // Садоводство и виноградарство. - М., 2011. - № 3. - C. 14-17.

7. Сазонов Ф.Ф. Эффективность возделывания смородины чёрной в югозападной части Нечерноземья России / Ф.Ф. Сазонов // Вестник Брянской ГСХА. Брянск. - Изд-во Брянской ГСХА, 2013. - № 3 (2013). - С. 10-13.

8. Сазонов Ф.Ф. Селекция как метод защиты смородины чёрной от патогенов / Ф.Ф. Сазонов // Агро-ХХІ, ООО «Издательство Агрорус», 2014. - № 4-6 (99). - С. $15-$ 17.

9. Сазонов Ф.Ф. Селекционный потенциал смородины чёрной и возможности его реализации: Автореф. дис. ... д-ра с.-х. наук: 06.01.05 / Ф.Ф. Сазонов. - Брянск, 2014. $38 \mathrm{c}$.

10. Сазонов Ф.Ф. Оценка технологических качеств плодов исходных форм смородины чёрной и их потомства / Ф.Ф. Сазонов, И.Д. Сазонова // Вестник Брянской ГСХА. - Брянск: Изд-во Брянский ГАУ, 2015. - № 1 (2015). - С. 29-33.

\section{Определение количества летучих жирных кислот в мясном фарше с пищевой} добавкой на основе лишайников

\author{
Николаев Г.Д., студент, \\ E-mail: gansgavril@mail.ru \\ Степанова А.В., стариий преподаватель, \\ E-mail: stepav@inbox.ru \\ Северо-Восточный федеральный университет, \\ 2. Якутск
}

Метод определения летучих кислот применяется только при разногласиях в оценке свежести мяса. Сущность его заключается в том, что при хранении в мясе и 